\title{
蛇行河川における河床形状発達に関する 一次元モデル計算 \\ 1-D MODELING OF BED DEFORMATION IN A MEANDERING RIVER
}

\author{
松延和彦 1 ・安藤誠 2 ・石川忠晴 3 \\ Kazuhiko MATSUNOBU, Makoto ANDO and Tadaharu ISHIKAWA \\ 1学生会員 修(工) 東京工業大学 大学院総合理工学研究科環境理工学創造専攻 \\ （三226-8502 横浜市緑区長津田町4259 G5-3） \\ 2学生会員 学(工) 東京工業大学 大学院総合理工学研究科環境理工学創造専攻（同上） \\ 3 フェロー 工博 東京工業大学 大学院総合理工学研究科環境理工学創造専攻（同上）
}

\begin{abstract}
In a meandering river, the interaction of flow and bed deformation intensifies the stream shift. It is an important problem how to describe this process in the modeling of meandering river. This paper presents the method for simulating the time evolution of river bed topography in one dimension on the basis of existing meandering flow model. First, the fitting method for the bed topography of channel experiment data is discussed for the model calculation. The result of stream shift calculation under the condition of the fitted bed topography agrees roughly with the experiment data. After that, this paper mentions how to calculate the bed deformation, adding the continuity equation of bed load in one dimensional flow model. Although the result partially agreed with the experiment data, the phase lag of bed undulations to channel curvature was underestimated. Therefore, the method how to correct the equation and express the phase lag well is also discussed.
\end{abstract}

Key Words : river meandering, one dimensional modeling, time evolution of river bed topography, continuity equation of bed load

\section{1. はじめに}

河川流路の蛇行現象に関しては自然地理学や河川工学 の分野で古くから注目され, 数々の事例研究 ${ }^{1), 2)}$ や実験 的研究 ${ }^{33) 4}$ が行われてきた. また，その知見に基づいた現 象の数值モデルも提案されている. 近年の計算機と流体 数值解析技術の発達により，二次元あるいは三次元での 水理計算と流砂量計算を組み合わせた平面二次元河床変 動解析が可能となっている. しかしながら, 蛇行発展の 計算では，水路形状の変化に伴い計算格子を再設定して 流れの解析を行う必要があり, 境界が固定された河床変 動に比較して計算負荷が大きい. このため, 現状では比 較的短い河道区間の短期的計算に留まっている5).

これに対して，蛇行現象の大局的特性を一次元解析に より把握する試みがなされている. Ikedaらのは「蛇行河 川の河床横断勾配が水路軸曲率に比例する」という経験 的関係を用い，側岸浸食速度が流速偏差に比例するとい う仮定のもとに, 蛇行流路発達の一次元モデル(bend equation)を提示している.

さて，この経験的関係は，蛇行形状と河床勾配の関係 を概略的に示している7)ものの，現実的には水路の横断 勾配と曲率との間に位相差が存在することが水路実験8) により確認されている. この問題を解決するためには, 流れの計算と河床変動計算をカップリングした新たな一 次元モデルの開発が必要であると考えられる.

流れ場の計算に関して，石川・劉”は，Ikedaらが考慮 している鉛直平均的な横断方向流れに，湾曲により生じ る二次流の影響10)を加え, 蛇行河川の浸食・堆積の原因 となる主流シフトを一次元的に計算することを試みてい る. そして，種々の単湾曲・蛇行水路において，実験結 果と良好に一致する計算結果を得ている.ただし，これ らはいずれも平坦固定床の水路における議論に留まって いる.

本論文では，石川・劉のモデルを基礎として，流れと 流砂の交互計算により，蛇行河川における河床形状の発 達を一次元的に表現する手法について議論する.まず, 移動床水路実験における平衡河床形状について, 一次元 
モデルに適合する関数形で地形のフィッティングを行う. 次に，その水路形状において流れ場の計算を行い，側岸 の浸食・堆積により河床地形変化を生じた水路において も，主流シフトが適切に表現されることを確認する.さ らに，それを一次元化した流砂の連続式と組み合わせる ことで，水路床形状の発展の再現性を検証する.

\section{2. 水路床形状のフィッティング}

\section{(1) 対象水路}

本研究で対象としたのは，長谷川 ${ }^{8)}$ の実験水路である. 水路諸元を表-1に示寸. 水路の平面形状は，蛇行偏角が 河道縦断距離に関して $\sin$ 関数で分布を取るsin-generated curveで定義されている.

表-1の水理条件のもとで，十分な通水時間を経て得ら れた平衡状態における河床地形を図-1に示寸。理想的に は半蛇行長ごとに対称形となるが，実際の実験データは やや異なる. 後の検証のため, 図-1を半蛇行長ごとに平 均化し, 図-2に示寸. 水路の曲率と河床の横断勾配の間 には明らかな位相差が存在する. 水路床は内岸側で堆積, 外岸側で浸食が発生しているが，横断勾配は前者が小さ く, 後者が大きい. 寸なわち, 横断面は上に凸な形状と なる．堆積による河床高の上昇は，曲率が最大となる付 近の内岸で顕著となり，そこから下流に向かうに従って 水路中央に伸びている. 一方, 横断平均的な河床高さに ついては，縦断的にほとんど変化がないと見られる。

\section{（2）フィッティング手法}

図-1の河床形状について，以下に述べる手順で最小二 乗法によるフィッティングを行う.

まず，横断面の関数形を定め，各横断面にフィッティ ングを適用する. 一次元蛇行モデルで最も重要なファク ターは, 流速や河床地形の左右岸での差であり, これは 1次のモードのみでも表現できる. しかしながら, 本研 究では, それに加えて (1)で述べた堆積側と浸食側の形 状の差を最も単純に表現できる2次関数形により近似す る.

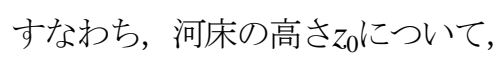

$$
\overline{z_{0}}(s, n)=a_{1}(s) \cdot b \eta-a_{2}(s) \cdot b\left(\eta^{2}-1 / 3\right)
$$

とする。ここに, $(s, n)$ : それぞれ縦断, 横断座標, $a_{i}(i=1,2)$ : 形状係数, $b$ : 水路半幅, $\eta=n / b$ である. $a_{2}$ の項 に係数-1/3を加えることによって, 式(1)を横断積分する 際， $a_{2}$ 項が 0 となる. したがって, 横断平均の河床高さ は0となっている．また， $a_{1}$ は横断平均勾配を表す，以 下では，これを1次フィッティングと定義する.

図-1に示した2つの横断測線A,Bについて，図-3に横断 面形状を黒線で，その1次フィッティング結果を赤線で 示す. 2測線いずれについても, 高次のモード分の差異 が若干残るものの, 横断面の特徵を概略的に表現できて いる.

次に, 周期境界を適用した一次元計算のため, 係数 $a_{i}(i=1,2)$ について, 縦断方向にフィッティングを行い, 周期関数化する. 以下では, これを 2 次フィッティング と定義する.まず, 幾何的な意味が比較的明確な $a_{1}$ の 1 次フィッティングによる縦断分布を図-4の黒線に示す. 縦断分布について， $a_{1}$ は蛇行長と同一の波長の周期関数 で近似できるように見受けられる. 三角関数での近似を 適用した2次フィッティング結果を, 図-4の赤線に示す. 黒線の縦断分布を良好に近似できている.

$a_{2}$ の縦断分布を図-5の黒線に示寸. $a_{1}$ が0に近い值とな る $s=0.6[\mathrm{~m}]$ と $s=1.7[\mathrm{~m}]$ 付近を除くほぼすべてのsについて $a_{2}>0$ となっている. これは，(1)で述べた横断河床形状 が上に凸になるという性質を示寸。つまり， $a_{2}$ は $a_{1}$ との 連動性が強い係数である.ただし， $a_{2}$ は $a_{1}$ および蛇行長 に対して倍振動の周期関数である. 一次元での表現を単 純化するため, $a_{2}$ と $a_{1}{ }^{2}$ の相関を取ることにより， $a_{2}$ の2 次フィッティングを $a_{1}$ の関数として表す.

$a_{1}^{2}$ の縦断分布を図-5に青線で示寸. 両者は比較的類似 した分布形を示寸が，わずかに位相差を持つことが見て 取れる，ここで，両者の相互相関係数を取り，それが最 大值を取る $s$ を位相のずれ $s_{0}$ とすると, $s_{0}=0.06[\mathrm{~m}]$ となる. このときの相関係数は 0.934 である.

縦軸に $a_{2}(s)$, 横軸に $\left\{a_{1}\left(s-s_{0}\right)\right\}^{2}$ を取ってプロット し, 図-6に赤色の点で示寸. 図-6の近似直線式加ら

表-1 蛇行実験水路の諸元

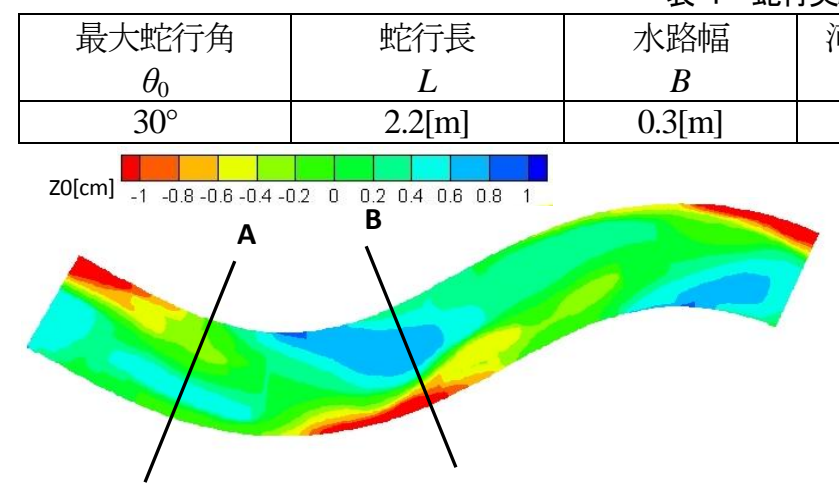

図-1 蛇行実験水路での平衡河床形状

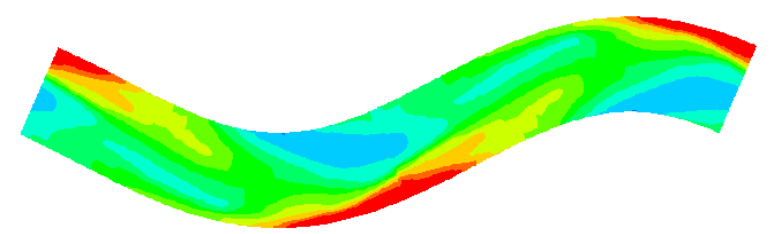

図-2 半蛇行長ごとに平均化した平衡河床形状 

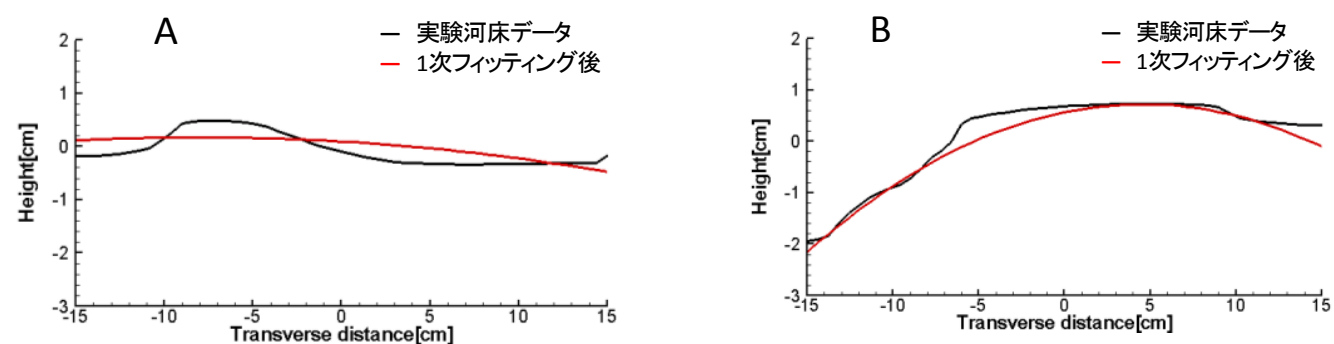

図-3＼cjkstart横断面形状フィッティングの一例

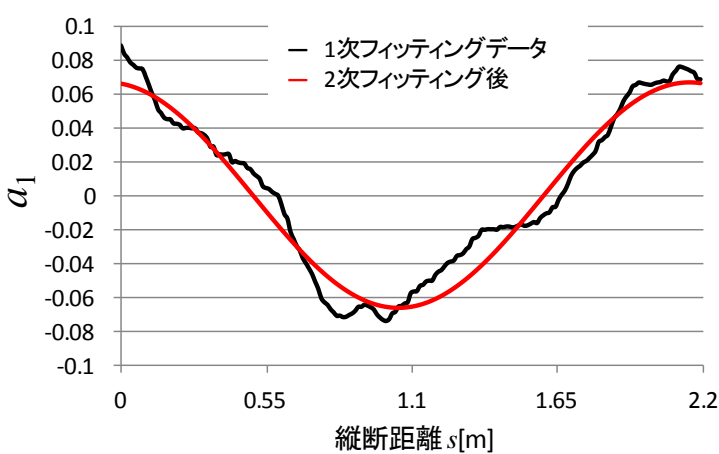

図-4 $\quad a_{1}$ の縦断分布とその2次フィッティング

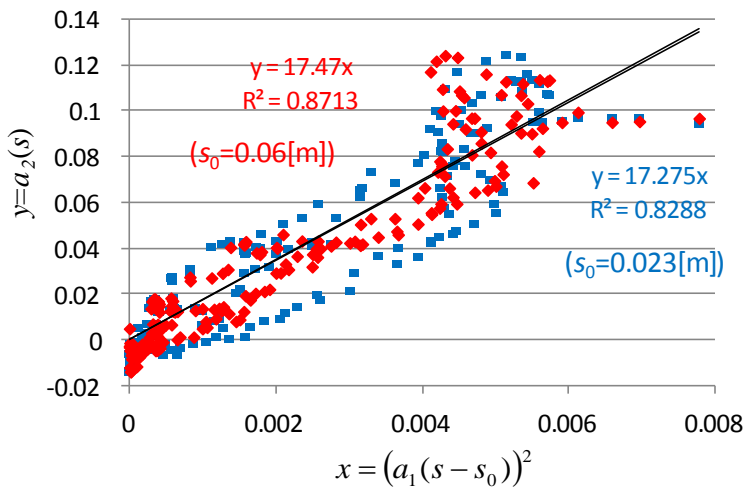

図-6 位相差を考慮した $a_{2}$ と $a_{1}^{2}$ の関係

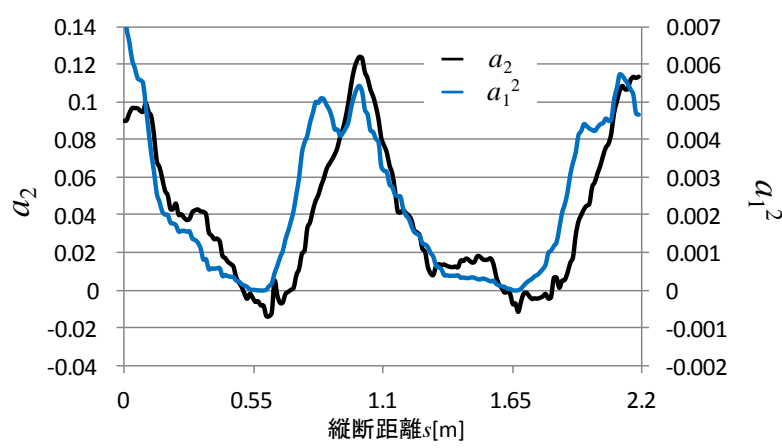

図-5 $a_{2}$ と $a_{1}^{2}$ の縦断分布

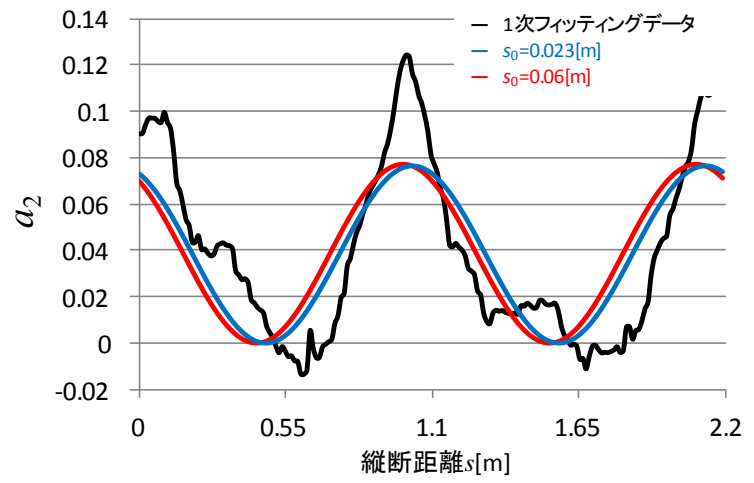

図-7 $a_{2}$ の2次フィッティング

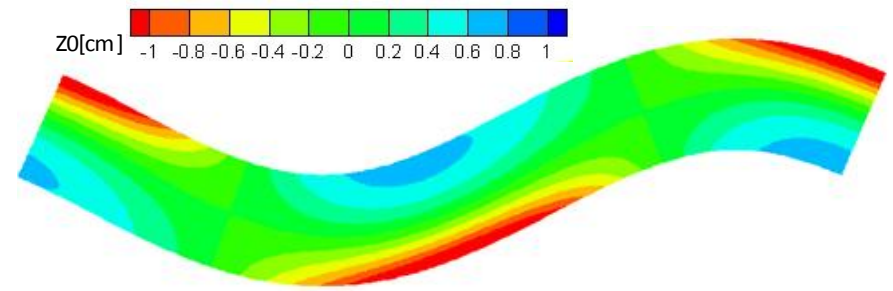

図-8＼cjkstart周期関数化された平衡河床形状

$$
a_{2}(s)=17.47\left\{a_{1}(s-0.06)\right\}^{2}
$$

という式で表される．簡単な式形にもかかわらず，概ね 良い相関が取れているため，式(2)を利用して $a_{2}$ の 2 次 フィッティングを行う.

式(2)による， $a_{2}$ の2次フィッティング結果を図-7の赤 線に示した．黒線とは位相のずれが残つている。ここで， 改めて相関係数が小さくならない範囲で，図-7の位相を 良く表現できる值を取ることを試みた。このとき， $s_{0}=0.023[\mathrm{~m}]$ であり，相関係数は0.911である.

結果を図-6, 図-7に青色で示した。確かに位相のずれ は小さくなっているが，一方で明らかに式(2)のデータの 方が図-6の相関は強い. この点はこのフィッティング手
法の限界であると解釈し，本研究では，式(2)を採用する こととした.

図-4と図-7で2次フィッティングを行った $a_{i}(i=1,2)$ から 求められる河床形状の平面分布を図-8に示寸．2段階の フィッティングにより, 堆積箇所の分布が中央に伸びる ことなどの情報は失われるものの，一次元モデルでの計 算に適合した河床地形が得られた.

\section{3. 平衡河床形状における主流シフトの解析}

（1）河床形状の変更を考慮したモデル化

図-8に示した河床地形の条件下で，石川・劉9)の一次 
元モデルにより流況を求める. $(s, n)$ 座標系での運動方程 式と連続式は式(3)〜(5)の通りである.

$$
\begin{aligned}
& \frac{1}{1+\sigma n} u \frac{\partial u}{\partial s}+v \frac{\partial u}{\partial n}+w \frac{\partial u}{\partial z}+\frac{\sigma}{1+\sigma n} u v \\
= & -\frac{1}{1+\sigma n} g \frac{\partial h}{\partial s}+\frac{1}{1+\sigma n} g I_{s}+\varepsilon \frac{\partial^{2} u}{\partial z^{2}} \\
& \frac{1}{1+\sigma n} u \frac{\partial v}{\partial s}+v \frac{\partial v}{\partial n}+w \frac{\partial v}{\partial z}-\frac{\sigma}{1+\sigma n} u^{2} \\
= & -g \frac{\partial h}{\partial n}+\frac{1}{1+\sigma n} g I_{n}+\varepsilon \frac{\partial^{2} v}{\partial z^{2}} \\
& \frac{1}{1+\sigma n} \frac{\partial u}{\partial s}+\frac{\partial v}{\partial n}+\frac{\partial w}{\partial z}+\frac{\sigma}{1+\sigma n} v=0
\end{aligned}
$$

ここに， $(u, v, w)$ : それぞれ $s, n, z$ 方向の流速， $\sigma$. 水路中 心軸の曲率, $h$ : 水深, $g$ : 重力加速度， $\left(I_{s}, I_{n}\right)$ : それぞれ $s$, $n$ 方向の水路床勾配, $\varepsilon$. 鉛直方向渦動粘性係数である.

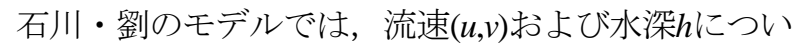
$\tau$

$$
\begin{gathered}
u=u_{0}\left\{1+\beta_{1}(\xi) \eta\right\}\left\{\phi(\zeta)+\beta_{2}(\xi) \psi_{1}(\zeta)\right\} \\
v=u_{0}\left\{\beta_{3}(\xi) \psi_{2}(\zeta)+\beta_{4}(\xi)\left(1-\eta^{2}\right) \phi(\zeta)\right\} \\
h=H_{0}\left\{1+\beta_{5}(\xi) \eta\right\}
\end{gathered}
$$

と仮定し，一次元化している. ここに， $u_{0}$ : 断面平均流速, $H_{0}$ : 横断平均水深, $\xi=s / b, \zeta=z / h, \phi$ :直線流路における流速 分布, $\psi_{1}, \psi_{2}: 2$ 次流によって生じる流速分布である. $\beta_{i}(i=1,2, \cdots, 5)$ は未知変数であり, 物理的な意味は表-2に 示す通りである.

表-2 各変数の物理的意味

\begin{tabular}{|c|c|}
\hline 変数 & 変数の物理的意味 \\
\hline$\beta_{1}$ & 主流速の横断方向勾配 \\
\hline$\beta_{2}$ & 鈆直方向の流速一様化 \\
\hline$\beta_{3}$ & 二次流強度 \\
\hline$\beta_{4}$ & 横断方向への全層的偏り \\
\hline$\beta_{5}$ & 水深の横断方向変化率 \\
\hline
\end{tabular}

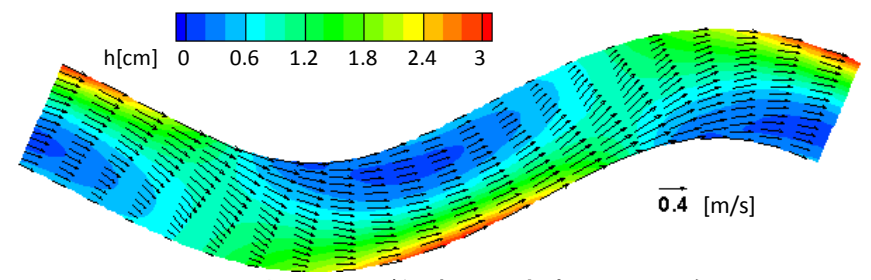

図-9 水深および鉛直平均流速の平面分布

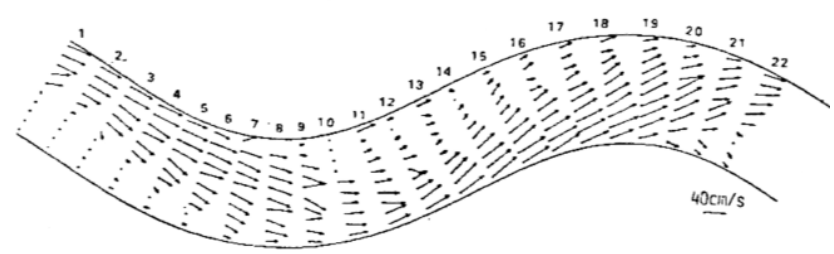

図-10＼cjkstart実験水路における鉛直平均流速の分布
本モデル計算において変更すべき式は，式(8)である. 横断河床形状を式(1)で表される2次関数に変更している ため, 一次元化する際の積分領域となる横断面も変化す る.そこで，水深 $h$ に関して， $a_{2}$ 項の追加に対応する補 正項が必要となる。これを含めると，本モデルでの水深 hの式は,

$$
h=H_{0}\left\{1+\beta_{5}(\xi) \eta+\frac{b}{H_{0}} a_{2}(s)\left(\eta^{2}-1 / 3\right)\right\}
$$

となる. $a_{2}$ は式(2)で示される $a_{1}$ の関数である. 式 (6),(7),(9)を式(3)〜 (5)に代入し，各 $\beta_{i}$ に対応する重み関数 を掛けて断面積分を行い，方程式を導出する. 導出の詳 細な手順については，石川・劉の文献を参照されたい.

\section{（2）計算結果}

本モデルでの計算結果について，鉛直平均流速および 水深の横断分布を求め, 可視化したものを図-9に示す. また，長谷川の実験において，河床が平衡状態に達した 段階での鉛直平均流速の平面分布を図-10に示す．主流 シフトによって流線が外岸側へ向から傾向を持っている 点，およびそれが慣性による位相の遅れを持つ点につい ては，大局的に表現できていることが示されている.

図-11に $\beta_{1}$ の縦断分布を示す．実験データについては, 横断方向に直線近似して求めた $\beta_{1}$, およびそれを三角関 数によりフィッティングしたものを破線で示した. 計算 結果と実験データの位相差は $1 / 15$ 蛇行長に対応する $24.5^{\circ}$ であり，十分とは言い切れないが概ね良好な結果 と言える. 従って，このモデルに流砂式を組み込むこと で，河床形状の変化を概略的に描けることが期待される.

\section{4. 河床形状の発達に関する計算}

\section{（1）一次元モデルによる地形変化の表現方法}

本論文において， $z_{0}$ は式(1)および式(2)により，実質的

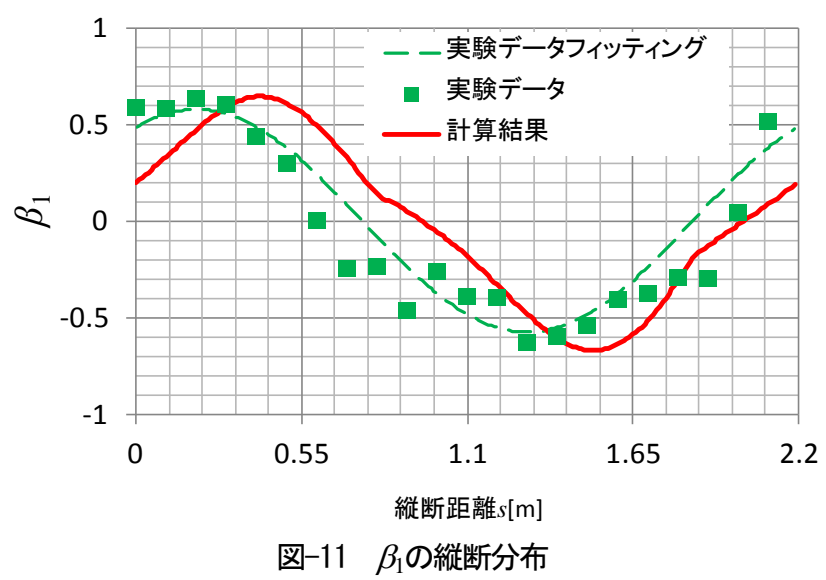


に $a_{1}$ の1変数のみによって一次元化されている. ここで は，流砂の連続式から， $a_{1}$ の時間変化 $\dot{a}_{1}$ を求める計算を 組み込み，それと前章で議論した流れの計算とを交互に 繰り返すことにより，河床形状の発達過程を一次元的に 表現することを試みた。

流砂の連続式の本来の式形は，式(10)に示寸とおりで ある.

$$
(1+\sigma n) \frac{\partial z_{0}}{\partial t}=-\frac{1}{1-\lambda}\left\{\frac{\partial q_{s}}{\partial s}+\frac{\partial(1+\sigma n) q_{n}}{\partial n}\right\}
$$

ここに， $\lambda:$ 粒子の間隙率， $\left(q_{s}, q_{n}\right)$ はそれぞれ,$n$ 方向の流 砂量である. 右辺は流砂量の二次元発散を示しており， 負号は発散が正となる箇所で河床の高さが低下し，負と なる箇所で上昇することを意味している.

式(10)を一次元化する方法として，石川・劉による流 れの計算と同様に，重み関数を掛けて横断方向に積分し， $\dot{a}_{1}$ に対応する方程式を導出することが考えられる.

しかしながら, 後に示寸通り, 流砂式は分数関数を含 むため，その積分は単純な関数形で表すことができない． その一方で， $a_{1}$ の変化を示寸際に必要なファクターは, 変数 $\beta_{1}$ に対応する主流シフトに起因する $q_{s}$ の横断偏差量, および横断方向流れを表す变数 $\beta_{3}$ と $\beta_{4}$ に起因する流砂量 $q_{n}$ である.

本研究では以下のような手法を利用し，それらの効果 を単純化して表すこととした。 縦断中心線を境界として 水路を横断方向に2分割し，それぞれの領域における流 砂量の収支を求めることにより， $\dot{a}_{1}$ を計算する. このと き， $n$ 方向の流砂の輸送に関しては，両端に壁境界を適 用し，水路中心軸を跨ぐ輸送量の夕を考慮する．概念図 を図-12に示す．図-12の右岸側，左岸側での流砂量の収 支は，それぞれ

$$
\begin{gathered}
\int_{-1}^{0}(1+b \sigma \eta)\left(-\dot{a}_{1} b \cdot \eta\right) d \eta=-Q_{r} \\
\int_{0}^{1}(1+b \sigma \eta)\left(-\dot{a}_{1} b \cdot \eta\right) d \eta=-Q_{l} \\
Q_{r}=\frac{1}{1-\lambda}\left(\frac{\partial q_{s r}}{\partial s}+\frac{q_{n}}{b}\right), Q_{l}=\frac{1}{1-\lambda}\left(\frac{\partial q_{s l}}{\partial s}-\frac{q_{n}}{b}\right)
\end{gathered}
$$

と表される. 式(11),(12)から $\dot{a}_{1}$ を計算し, 各横断面につ いて, 時間陽解法により次ステップの $a_{0}$ と $a_{1}$ を求める. 流砂量の計算は，芦田・道上 ${ }^{11)} の$ 式(13)を用いる.

$$
q_{*}=17 \tau_{*}^{1.5}\left(1-\frac{\tau_{*_{c}}}{\tau_{*}}\right)\left(1-\sqrt{\frac{\tau_{*_{c}}}{\tau_{*}}}\right)
$$

ここに， $q_{*}$ :無次元流砂量 $\left(=q / \sqrt{R_{0} g d^{3}}\right), \tau$ : 無次元掃流 力 $\left(=\tau / R_{0} \rho g d\right)$ である. $R_{0}$ は土粒子の水中相対比重で あり，1.65としている．また，衿は無次元限界掃流力で， ここでは0.05で一定とする.

ては式(14)から計算する.

$\tau_{*}=\left(\begin{array}{l}\tau_{s^{*}} \\ \tau_{n^{*}}\end{array}\right)=k_{1}\left(\begin{array}{l}f u_{b} \sqrt{u_{b}^{2}+v_{b}^{2}} \\ f v_{b} \sqrt{u_{b}{ }^{2}+v_{b}^{2}}\end{array}\right)+k_{2}\left(\begin{array}{l}R_{0} g \cdot I_{s} \\ R_{0} g \cdot I_{n}\end{array}\right)$

ここに, $g$ :重力加速度, $u_{b}, v_{b}$ は底面流速のs方向および $n$ 方向成分, $f$ は摩擦保数である. 式(14)の右辺第一項が河 床に作用する流体力，第二項が重力の効果を表している。 実際の河床形状はフィッティングを施したそれと比較し て，局所的な洗掘により勾配が大きくなっている箇所が 生じる.このため, 実際の重力の影響は，モデル化され た河床形状で計算するものよりも大きくなる.この効果 を流体力との比率で考慮し，その逆比を有効応力に関す る補正係数 $k_{1}$ として流体力に乗じることとした．本計算 においては， $k_{1}=0.44$ としている， $k_{2}$ は砂粒の体積と水流 に触れる面積の比で，2d/3である，なお，式(14)におけ る $u_{b}, v_{b}$ の計算において, 前述の $a_{1}$ の変化を示寸際に必要 なファクターに含まれない変数 $\beta_{2}$ の影響は無視している。

図-13に平衡河床地形のコンターを示寸，図-2および 図-8と比較して，最大洗掘深については概ね一致するも のの，位相についてはやや大きな差が存在する.

\section{（2）位相差の修正}

（1）では流砂の計算に芦田・道上の式を用い，横断方 向に2分割したコントロールボリュームにおける流砂の 連続式を解いた。 芦田・道上の式は直線的な水路につい ての式として導出されているものである. それに対し， 蛇行水路に関しては, 長谷川の実験に見られるように, 曲率と流砂による地形変化の間に位相差が存在すること が知られている.（1)の計算結果ではこの位相差が過小 評価されているため，ここでは次のようにしてそれを補 正することを試みた.

計算に利用する位相差の補正式は,

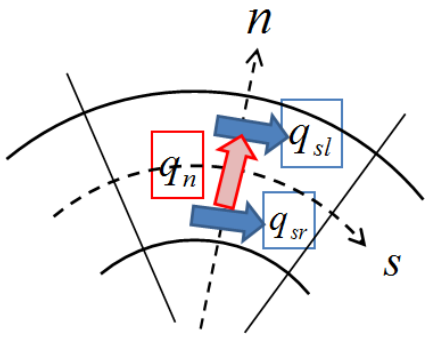

図-12 流砂計算の概念図

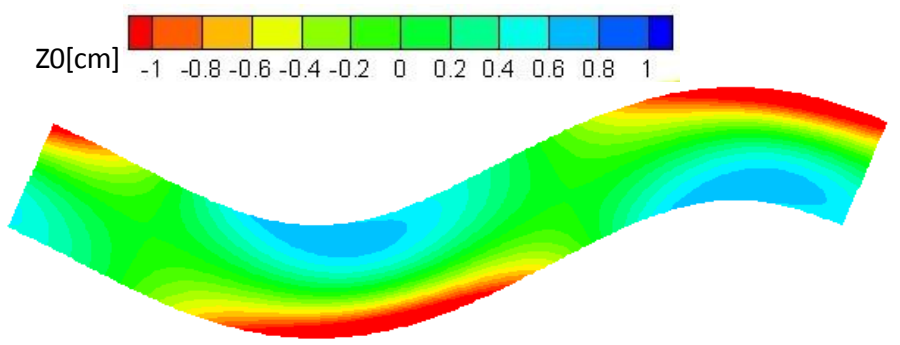

図-13蛇行発達計算によって求められた平衡河床 


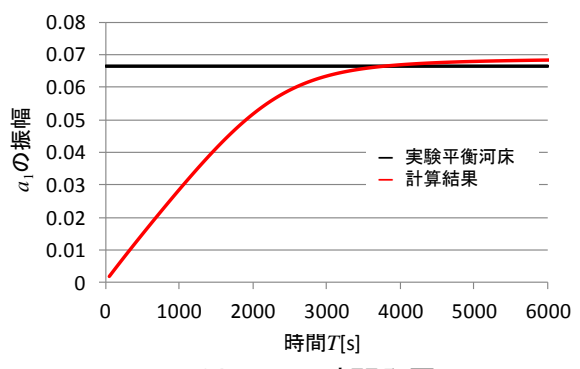

図-14 $a_{1}$ の時間発展

$$
\frac{\partial q_{s}}{\partial s}=C\left(q_{s 0}-q_{s}\right)
$$

ここに, $q_{50}$ : 芦田・道上の式から計算される流砂量, $q_{s}:$ 補正後の流砂量である。Cは位相の遅れを示す係数であ り，長さの逆数の次元を持つ.ここでは試行錯誤により， $C=1 / 0.04$ とした。 この0.04[m]という值は，図-12と図-8 における位相差の $1 / 5$ に対応する.

計算による $a_{1}$ の振幅の時間発展を図-14に赤線で示す. 黒線は実験平衡河床のフィッティング值である.

$T=4500[\mathrm{~s}]$ [おいて，河床形状はほぼ平衡状態となってお り，振幅の大きさがよく一致している.

図-15に平衡河床地形のコンターを示す。最大洗掘深 の一致度はほぼ変わらず，位相が図-2とより類似した結 果が得られた。

\section{5. おわりに}

本論文では，蛇行河川における河床形状の発達を一次 元的に表現するモデルの構築を目的とし，移動床水路に おける平衡河床のフィッティング方法について議論を 行った. また, フィッティングした平衡河床の条件下で 主流シフトの計算を行い，これに一次元化した流砂の計 算を組み込むことにより河道形状の発達過程の再現を試 みた. 主要な結論を以下に示寸.

1) 長谷川の移動床蛇行水路における平衡河床の横断 形状が，2次関数形で概ね近似出来ることを示した。 また，横断平均勾配 $a_{1}$ と 2 次偏差係数 $a_{2}$ の関係につ いて, $a_{2}$ と $a_{1}{ }^{2}$ の間に位相差を持った相関があるこ とを示した.

2) 石川・劉の一次元モデルに, 2次関数形の横断形状 に対応する改良を行った，計算結果について，水 深の浅い箇所では流速分布に大きな差異が見られ たものの，主流シフトに関しては大局的に水路実 験結果と一致する計算結果が得られた.

3) 一次元化した流れと流砂の交互計算ルーチンを構 築した. 平衡状態における河床の横断勾配の分布 について, 最大洗掘深は実験結果と概ね一致する 計算結果となった。しかし，曲率と横断勾配の位 相差に関しては十分に表現できなかった.

4) 主流方向の流砂量 $q_{s}$ に関して, 流砂の非平衡性を導
入して計算を試みた。試行錯誤により，位相の遅 れを示す係数 $C$ を位相差の $1 / 5$ から決定することで, 実験結果と比較的良く一致する結果が得られた.

本計算は一次元モデルによるものであり, 蛇行による マクロな視点での河床形状の発展を描くことができる.

ただし，現状では解析に多くの仮定を含むため，異な る蛇行水路においての計算結果を分析し，それらの仮定 の妥当性を検証することが必要である.

\section{参考文献}

1) L.B. Leopold and M.G. Wolman: River Meanders, Geol. Soc.Am. Bull, Vol.71, pp.769-794, 1960.

2) Hickin, E.J. and Nanson, G.G.: The Character of Channel Migration on the Beatton River, Northeast British Columbia, Canada. Geol. Soc. Am. Bull, Vol.86, pp.487-494, 1975.

3) Friedkin, J.K.: A laboratory study of the meandering of alluvial rivers, U.S. Army Corps of Engineers Waterways Experiment stations, Vicksburg, MS, USA, 1945.

4）芦田和男，村本嘉雄，奈良井修二，塩入淑史 : 河道の変動 に関寸る研究(1), 京大防災研究所年報第13号B, pp.243-260, 1970.

5) 例えば, Dong Chan and Jennifer G. Duan: Case Study: Two Dimensional Model Simulation of Longitudinal and Lateral Channel Migration Processes in West Jordan River, Utah. J. Hydraul. Eng. Vol.134, No.3, pp.315-327, 2008.

6) Ikeda, S., Parker, G. and Sawai, K.: Bend theory of river meanders, Part 1. Linear development, Journal of Fluid.Mech., Vol.112, pp.363-377, 1981.

7) Engelund, F.: Flow and bed topography in channel bends, Journal of Hydraulic Division, Proc. ASCE, Vol.100, pp.1631-1648, 1974.

8) 長谷川和義 : 蛇曲流路における流れと平衡底面形状に関す る研究，土木学会論文報告集，No.338,pp.105-114, 1983.

9）石川忠晴・劉暢 : 河川横断方向の主流シフトの一次元モデ ル化に関する研究，土木学会論文集B1，Vol.69, No.1, pp.60$70,2013$.

10) 石川忠晴・金舜範 : 湾曲部の二次流に関寸る基礎的研究, 土木学会論文集, No.375/II-6, pp.143-149, 1986.

11) 芦田和男, 道上正規 : 移動床流れの抵抗と掃流砂量に関す る基礎的研究，土木学会論文集，206号，pp.59-69, 1972.

(2013. 9. 30受付) 